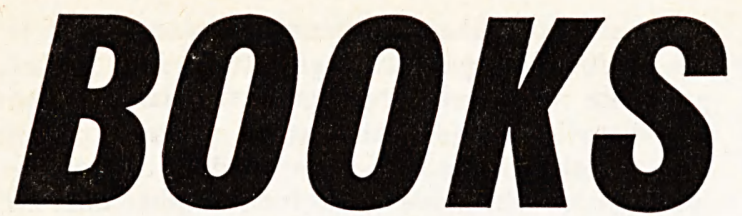

The impending medical revolution

by Deryck Taverner

Hodder \& Stoughton, 32s. 6 d.

IN AN IMPRESSIVE review of the impact of molecular biology and genetics on medical thinking, Dr. Deryck Taverner makes the telling point that medicine, far from becoming more scientific in our day, is merely becoming more technological. He demonstrates the limitations of the concept of disease as an entity, and of the nonsense of dividing illness into the real and the imaginary: it is noteworthy that in looking at the phenomenon of illness from the ground of the biological science, he has come to conclusions very similar to those of Dr. Michael Balint and his followers, who have proceeded from the ground of psychoanalysis.

The Impending Medical Revolution, the author envisages, is concerned largely with the redeployment of medical manpower, engineering equipment and hospital beds. It is the perspective of a humane and imaginative hospital scientist who is trying to harness the new technologies of industrial cost effectiveness to the explosive demand for medical care.

It is, however, when he looks beyond the hospital milieu of his own experience that Dr. Taverner falters. He wants to enhance the role of the general practitioner, but he can see no other way to do so than to digest him into the new hospital system. One sympathises with this problem: it is difficult to programme the therapeutic effect of the doctor/patient relationship into a system of maximised manpower efficiency. What he proposes is a speeded-up evolution in the direction in which we are already travelling. Yet his title expresses a real need. When the medical revolution comes, it may well take its inspiration from the intelligent laymen to whom Dr. Taverner addresses himself. Meanwhile, for those who would man the barricades, this book should be required reading.

Marshall Marinker

\section{Human aggression}

\section{by Anthony Storr}

\section{Allen Lane, 25s.}

To PUT it very simply, Dr. Storr's message is this: aggression is something we cannot eradicate, but must learn to control. Without it, the human species could not exist; because of it, the human species faces extinction. Without it, the individual human being would be reduced to nothingness; because of it, he may inflict appalling suffering on himself and others of his kind.

Granting Dr. Storr his whole premise-and as a layman it would be an impertinence on my part to challenge it, even if I were so minded-I am left with a large unanswered question. How do we distinguish between healthy and unhealthy aggression - between aggression that is constructive and aggression turned to hatred? 'The guard in a concentration camp,' says Dr. Storr, "who tortures his helpless victim is obviously acting aggressively.' And-as obviously, one may assume-destructively. But what of the judge who awards a thirty-year sentence for robbery? $\mathrm{He}$, too, according to Dr. Storr, is acting aggressively. Is he also acting destructively? If that is a matter of value judgement, which presumably it still is, it could be left unsettled in a Utopian society where man's natural aggression was fully controlled.
Dr. Storr, if he will forgive me for saying so, has given us an unaggressive book; unaggressive, because it is largely free of psycho. analytical dogma and correspond ingly generous with admissions of the colossal areas of ignorance in his own and complementary dis ciplines. Unaggressive, also, be cause in spite of its dazzling display of knowledge and its rigidly scientific approach, it is written in good, clear and declarative English.

If, as seems likely, it turns out to be a 'popular' book, so much the better-the more chance that its final plea for further research will be heeded. For what Dr. Storr says at the last would seem to me indis" putable. The problems that afflict the human species will never be soluble, until Man abandons reliance on his 'instincts', his 'common sense', his phantasies, and begins to seek the truth about himself.

Giles Playfair

\section{Four years old in an urban community}

by John and Elizabeth Newson Allen and Unwin, 60s.

JoHN AND Elizabeth Newson are psychologists with a special inter est in child-rearing practices. They study the causes and consequences of these practices in their social and material contexts. This is the second book in the Newsons' study of 700 Nottingham children and it concerns the children as they reach their fourth birthdays.

The book has the merit of attempting to find out how mothers and children actually behave. It uses the techniques not only of observation but also of interpretation of what the mothers actually say. This is done in an extremely sensitive manner and, although the authors might be accused of being 'unscientific', in my view their technique is rathe? more likely to give truthful result than many more formal and con ventionally acceptable methods. also think that this book shows ? more balanced outlook than the first, which is rather marred by repeated use of the word 'permis' 